AT-TAJDID: Jurnal Pendidikan Dan Pemikiran Islam

(p-ISSN: 2548-5784 |e-ISSN: 2549-2101)

Vol. (5) (01), (Januari-Juni) (2021), (42-49)

Doi: http://dx.doi.org/10.24127/att.v5i01.1503

\title{
PENGEMBANGAN MANAJEMEN SUMBER DAYA MANUSIA DALAM MENINGKATKAN KUALITAS PELAYANAN AKADEMIK
}

\author{
Vista Firda Sari \\ STEI Darul Qur'an Minak Selebah Lampung Timur \\ E-mail: vistafirdasari@gmail.com
}

\begin{abstract}
ABSTRAK
Strategi yang paling tepat dalam meningkatkan kualitas pelayanan akademik pada perguruan tinggi adalah dengan meningkatkan variabel yang ada pada kualitas pelayanan secara nyata, keandalan, responsivitas, jaminan, dan empati, dengan dibuktikan dengan ketersesuaian yang ada di lapangan, di antaranya kesesuaian kurikulum antara harapan dan kenyataan, kesesuaian sarana dan prasarana perkuliahan antara harapan dan kenyatan, kesesuaian pelaksanaan perkuliahan antara harapan dan kenyataan, dan kesesuaian pembimbing akademik antara harapan dan kesesuaian.
\end{abstract}

Kata Kunci: Manajemen Sumber Daya Manusia dan Kualitas Pelayanan Akademik

\begin{abstract}
The most appropriate strategy in improving the quality of academic services in tertiary institutions is to increase the existing variables in real service quality, reliability, responsiveness, assurance, and empathy, as evidenced by the suitability in the field, including curriculum compatibility between expectations and reality., the suitability of lecture facilities and infrastructure between expectations and reality, the suitability of lecture implementation between expectations and reality, and the suitability of the academic supervisor between expectations and conformity.
\end{abstract}

Keywords: Human Resource Management and Academic Service Quality

\section{A. PENDAhULUAN}

Era globlalisasi ini, jasa pendidikan memegang peranan yang bersifat vital guna mengembangkan dan meningkatkan kualitas sumber daya manusia. Namun, minat dan perhatian pada aspek kualitas jasa pendidikan, dapat dikatakan, baru berkembang dalam satu dasawarsa terakhir. Keberhasilan jasa pendidikan ditentukan dalam memberikan pelayanan yang berkualitas kepada para pengguna jasa pendidikan tersebut, yakni peserta didik (masyarakat).

Rencana pembangunan pendidikan jangka panjang 2005-2025 telah dijabarkan dalam empat tema pembangunan pendidikan, di antaranya peningkatan kapasitas dan modernisasi (2005-2009), penguatan pelayanan (2010-2015), penguatan daya saing regional (2015-2020), dan penguatan daya saing internasional (2020-2025). Rencana pembangunan ini Copyright $\odot$ 2020, Universitas Muhammadiyah Metro|42 
berimplikasi kepada pemangku kepentingan pendidikan, sehingga dalam pembangunan pendidikan nasional bertujuan untuk meningkatkan kualitas pelayanan pendidikan yang berdampak pada peningkatan kepuasan akademik setiap pengguna jasa pendidikan, utamanya adalah peserta didik.

Peningkatan kualitas pendidikan tinggi adalah sebuah keniscayaan yang harus dilaksanakan oleh penyelenggara pendidikan tinggi, baik pendidikan tinggi yang diselenggarakan oleh pemerintah maupun pendidikan tinggi yang diselenggarakan oleh masyarakat. Kualitas pendidikan yang dicapai, selama ini, terasa kurang memberikan bekal kepada lulusan perguruan tinggi. Hal tersebut dibuktikan dengan lemahnya daya saing lulusan perguruan tinggi di Indonesia di kancah internasional. Mahasiswa, sebagai pemangku kepentingan utama perguruan tinggi, sudah semestinya dapat memperoleh apa yang selama ini diinginkan.

Agar mahasiswa memperoleh apa yang diharapkan, pihak perguruan tinggi harus dapat mensinergikan antara harapan mahasiswa dengan visi, misi, dan tujuan organisasi. Sinergisitas harapan mahasiswa dan kepentingan perguruan tinggi akan tercapai apabila layanan akademik yang dilakukan mengedepankan aspek kualitas, fasilitas yang memadai, dan manajemen yang professional (Annur \& Suhono, 2019). Perguruan tinggi sesuai dengan visi, misi, dan tujuannya merupakan sebuah institusi penggarap dan penghasil sumber daya manusia yang unggul sebagai jembatan di dalam menghasilkan produk berkualitas untuk mampu berkompetisi di pasar global. Di mana mahasiswa merupakan elemen vital dan sentral dalam suatu perguruan tinggi, terutama bagi mahasiswa demi terwujudnya hasil yang berkualitas agar dapat memberikan kontribusi terbaik dalam pengabdiannya terhadap masyarakat.

Pengelola perguruan tinggi, tidak terkecuali, perlu juga memiliki obsesi untuk membangun komitmen yang tinggi terhadap peningkatan kualitas sesuai dengan biaya yang telah dikeluarkan oleh mahasiswa. Komitmen tersebut dibuktikan pengajar atau dosen yang memenuhi kualifikasi dan fasilitas pembelajaran yang memenuhi standar menjadi prasyarat utama untuk memberikan kepuasan kepada mahasiswa.

Pada sebagian perguruan tinggi, peran dosen memberikan kepuasan kepada mahasiswa dalam pembelajaran, sehingga biaya yang telah dikeluarkan oleh mahasiswa sepadan dengan apa yang diperolehnya. Sedangkan, ketersediaan fasilitas pembelajaran juga mempengaruhi kepuasan mahasiswa terhadap biaya yang telah dikeluarkannya. Fasilitas pembelajaran di perguruan tinggi, seharusnya, menggunakan fasilitas yang lebih baik, dikarenakan mahasiswa merupakan sosok yang tumbuh sebagai pribadi dan memiliki kematangan konsep diri, bergerak dari ketergantungan. Kematangan diri yang dimaksud ialah kematangan psikologis mahasiswa sebagai pribadi yang mampu mengarahkan diri sendiri.

Mendorong lahirnya kebutuhan psikologis, yakni keinginan dipandang dan diperlakukan orang lain sebagai pribadi yang mengarahkan dirinya sendiri, bukan 
diarahkan, dipaksa, ataupun dimanipulasi oleh orang lain. Tingkat kematangan merupakan salah satu faktor yang mendorong mahasiswa memberikan pandangannya terhadap sesuatu yang dapat mereka rasakan selama menjadi mahasiswa. Ada mahasiswa yang cukup senang dengan keadaan yang dirasakannya selama menjadi mahasiswa, baik dari sisi proses pembelajaran, fasilitas kampus, lingkungan maupun kehidupan kampus. Namun, ada pula mahasiswa yang merasa kurang ataupun tidak puas terhadap proses pembelajaran, fasilitas kampus, lingkungan dan kehidupan kampus. Sehingga, timbul ketidakpuasan dalam dirinya.

Mahasiswa, dalam hal ini, dapat dikatakan sebagai pelanggan perguruan tinggi yang mempunyai karakteristik relatif kompleks dan beragam. Sehingga, pelanggan tidak hanya tunggal, tetapi banyak pihak, dengan faktor atau kriteria kepuasan yang berbeda-beda. Salah satu pelanggan di perguruan tinggi, dalam hal ini mahasiswa, lebih cocok diidentikkan dengan istilah pemangku kepentingan, karena menunjukkan adanya banyak pihak pelanggan dengan faktor atau kriteria kepuasan yang berbeda antara satu dengan yang lainnya. jenis pemangku kepentingan perguruan tinggi yang lain, di antaranya adalah pemakai lulusan, masyarakat, serta dosen dan karyawan.

Mahasiswa adalah pemangku kepentingan inti, karena pihak yang berkepentingan dan langsung dipengaruhi oleh pembelajaran dan manajemen pengelola perguruan tinggi. Pihak pemakai lulusan dan masyarakat merupakan pemangku kepentingan yang berkepentingan terhadap hasil kontribusi nyata dari dosen dan karyawan, mahasiswa dan alumninya. Kontribusi penting yang dilakukan oleh dosen dan karyawan adalah layanan pembelajaran, manajemen dan pemberian fasilitas perkuliahan yang memadai, keamanan yang diterima dan adanya kehidupan serta lingkungan kampus yang nyaman bagi mahasiswa (Asnawan, 2021; Herawati, et al., 2020).

Kepuasan pengguna jasa pendidikan menjadi sangat penting bagi kemajuan perguruan tinggi. Kepuasan mahasiswa sebagai pengguna jasa utama menjadi tonggak bagi keberlangsungan suatu perguruan tinggi. Hal ini dikarenakan kepuasan mahasiswa akan berdampak pada loyalitasnya terhadap perguruan tinggi tersebut. Seorang pengguna jasa perguruan tinggi yang loyal akan menjadi aset yang sangat bernilai bagi perguruan tinggi, karena mahasiswa tersebut akan bersedia mempromosikan perguruan tingginya kepada orang lain, memberikan umpan balik positif, mengurangi pengaruh serangan dari para pesaing institusi sejenis, serta meningkatkan citra positif dari institusi tersebut.

Harga sebagai sesuatu yang harus diberikan oleh pengguna jasa untuk memperoleh sejumlah jasa dan pelayanan menjadi salah satu komponen dari pemasaran yang mempengaruhi pilihan pengguna jasa. Dalam beberapa kasus, ditemukan bahwa pengguna jasa tidak segan-segan untuk mengeluarkan biaya yang cukup tinggi untuk memperoleh produk yang berkualitas. Penentuan produk jasa 
dapat dikaitkan dengan konsep nilai bersih, semakin besar manfaat yang dirasakan dibanding biaya yang dikeluarkan akan dinilai oleh konsumen sebagai nilai positif.

Setiap mahasiswa menghendaki kepuasan maksimal dari setiap layanan yang terdapat di lingkungan kampusnya. Tentunya, dengan kepuasan maksimal yang didapat oleh mahasiswa akan dapat meningkatkan kesejahteraan bagi yang bersangkutan. Kepuasan adalah tingkat perasaan seseorang setelah membandingkan kinerja yang dirasakannya dibandingkan dengan harapannya. Tingkat kepuasan merupakan fungsi dari perbedaan antara kinerja yang dirasakan dengan harapan. Begitu juga dengan mahasiswa yang merupakan pelanggan dari perguruan tinggi. Mahasiswa akan merasa puas apabila harapan mereka dipenuhi dan senang apabila harapan mereka dilebihi. Kepuasan mahasiswa akan tercermin dari loyalitasnya kepada almamater dan tentunya akan menghasilkan yang baik kepada almamaternya.

\section{B. METODOLOGI}

Penelitian ini menggunakan pendekatan kualitatif dengan teknik pengumpulan data dengan teknik telaah dokumen atau biasa disebut dengan dokumentasi. Keabsahan data dilakukan secara triangulasi. Analisis data yang dilakukan bersifat induktif atau kualitatif berdasarkan fakta-fakta yang bersifat khusus, proses analisis data diawali dengan menelaah data yang diperoleh dari hasil dokumentasi yang telah disajikan dalam catatan tertulis dan lain sebagainya.

\section{HASIL DAN PEMBAHASAN}

Pengembangan konsep manajemen mutu terpadu di perguruan tinggi dapat memberikan kepuasan mahasiswa. Konsep tersebut memiliki tiga prinsip utama yang dapat dipakai sebagai acuan dalam menampilkan kinerja perguruan tinggi. Pertama, adanya kebulatan tekad untuk meningkatkan kualitas jasa perguruan tinggi secara terus-menerus dalam mempersiapkan mahasiswa menghadapi persaingan dalam dunia kerja. Kedua, perlu adanya perbaikan dan peningkatan sistem pengajaran dan pelayanan secara berkelanjutan, efektif, dan efesien. Ketiga, melaksanakan perubahan dalam perguruan tinggi dan mengikutsertakan masyarakat untuk berpartisipasi dalam perguruan tinggi. (Sularso, 1997:325).

Berangkat dari uraian tersebut di atas, perguruan tinggi pada dasarnya adalah industri jasa yang memberikan layanan atau jasa pendidikan yang tujuannya untuk memberikan kepuasan kepada pelanggannya. Dewasa ini, perguruan tinggi dihadapkan pada persoalan akan mutu dan akuntabilitas atau jasa pendidikan yang diberikannya. Sehingga, layanan mutu harus diberikan untuk memuaskan pelanggan. (H. A. R. Tilaar, 1994: 11).

Pelayanan akademik yang berkualitas akan mengarah pada kepuasan akademik mahasiswa sebagai pelanggan primer. Kepuasan akademik mahasiswa akan menghasilkan banyak keuntungan, di antaranya kemampuan mahasiswa akan terjamin secara baik dan perguruan tinggi akan terkenal dan menjadi rebutan. 
Sebaliknya, ketidakpuasan mahasiswa akan menimbulkan kerugian. Pendapat lain mengungkapkan, bahwa kepuasan akademik mahasiswa terhadap layanan akademik ialah adanya kesesuaian antara harapan dan kinerja layanan yang diterima olehnya. (Tampubolon, 2001: 70).

Organisasi yang fokus terhadap konsumen adalah pilihan strategis bagi dunia usaha dan industri agar mampu bertahan di tengah persaiangan yang semakin berkembang secara cepat. Salah satu cara yang bisa ditempuh adalah dengan melakukan peningkatan kualitas pelayanan. Persoalan kualitas menjadi harga mati oleh perusahaan maupun lembaga agar dapat bertahan di tengah ketatnya persaingan. Tuntutan akan kualitas dari konsumen pelayanan tidak dapat dielakkan oleh perusahaan. Begitu pula dalam perguruan tinggi, di mana tujuan akhir dari pelayanan akademik yang diberikan ialah kepuasan mahasiswa.

Mahasiswa mengharapkan pelayanan yang berkualitas dengan berbagai sumber yang menjadi harapan. Sehingga, kualitas pelayanan yang diberikan berawal dari harapan mahasiswa dan berakhir pada kepuasaan mahasiswa.

Kesadaran akan kualitas dari identifikasi persyaratan-persyaratan konsumen sampai dimulainya gagasan konsep produk atau pelayanan sampai masa purna beli. Kualitas pelayanan yang diberikan sesuai dengan spesifikasi dari pelanggan. Kualitas pelayanan adalah sejauh mana pelayanan yang diterima konsumen sesuai dengan harapannya. Pendekatan kualitas pelayanan akan sangat tergantung pada pelaksanaan sistem manajemen kualitas. (Rambat, 2006: 175).

Kualitas pelayanan berdasarkan ISO 9000 adalah derajat yang dicapai oleh karakteristik yang inheren dalam memenuhi persyaratan. Persyaratan dalam hal ini adalah kebutuhan atau harapan butuhan atau harapan yang dinyatakan, biasanya tersirat atau wajib. Kualitas pelayanan dapat diukur dari lima dimensi, sebagai berikut:

1. Bukti fisik, yakni kemampuan lembaga dalam menunjukkan eksistensinya kepada pihak eksternal.

2. Keandalan, yakni kemampuan lembaga untuk memberikan pelayanan sesuai dengan yang dijanjikan secara akurat dan terpercaya.

3. Ketanggapan, yakni suatu kemauan untuk membantu dan memberikan pelayanan yang cepat dan tepat kepada pelanggan dengan menyampaikan informasi yang jelas.

4. Jaminan dan kepastian, yakni pengetahuan, kesopansantunan, dan kemampuan para pegawai lembaga untuk menumbuhkan rasa percaya para pelanggan kepada lembaga yang terdiri dari beberapa komponen, di antaranya komunikasi, kredibilitas, keamanan, kompetensi, dan sopan santun.

5. Empati, yakni memberikan perhatian yang tulus dan bersifat individual atau pribadi yang diberikan kepada para pelanggan dengan berupaya memahami keinginan pelanggan. (Rambat, 2006: 148).

Dimensi-dimensi kualitas yang diuraikan oleh beberapa ahli menjadi sangat penting untuk diperhatikan guna memuaskan 
pelanggan. Terdapat tujuh dimensi dasar kualitas, sebagai berikut:

1. Kinerja, yakni tingkat absolut kinerja barang atau jasa pada atribut kunci yang diidentifikasi oleh para pelanggan.

2. Interaksi pegawai, yakni seperti keramahan, sikap hormat, dan empati ditunjukkan oleh masyarakat yang memberikan jasa atau barang.

3. Reliabilitas, yakni konsistensi kinerja barang, jasa, dan lembaga.

4. Daya tahan, yakni rentan kehidupan produk dan kekuatan umum.

5. Ketepatan waktu dan kenyamanan, yakni seberapa cepat produk diserahkan atau diperbaiki, seberapa cepat produk informasi atau jasa diberikan.

6. Estetika, yakni lebih pada penampilan fisik barang atau lembaga dan daya tarik penyajian jasa.

7. Kesadaran akan merk, yakni dampak positif atau negatif tambahan atas kualitas yang tampak yang mengenal merk atau nama lembaga atas evaluasi pelanggan. (Sularso, 1997: 244).

Beberapa pendapat tersebut di atas sejalan dengan pendapat lain yang mengungkapkan bahwa terdapat lima kriteria penentu kualitas jasa pelayanan, yakni keandalan, keresponsivan, keyakinan, empati, berwujud. Kelima kriteria tersebut akan mempengaruhi tanggapan dari pelanggan yang berupa harapan dan kenyataan yang pada akhirnya bermuara pada kepuasaan pelanggan. Pelanggan perguruan tinggi ialah pihak yang dipengaruhi oleh produk perguruan tinggi dan proses yang terjadi dalam produksi dan penyajian produk tersebut.
Lulusan perguruan tinggi adalah produk parsial. Apabila merasa puas atas pelayanannya, maka jumlah pelanggan akan terus bertambah dan keuntungan dalam berbagai bentuk akan meningkat. Pertambahan itu mengimplikasikan bahwa para pelanggan menghayati dan menikmati pelayanan yang dihasilkan oleh badan usaha jasa tersebut. Dengan kata lain, pelayanan yang terjadi pada suatu industri jasa mempengaruhi perasaan para pelanggan secara positif. Sebaliknya, apabila pelayanan tidak memuaskan, tentu pelanggan kecewa dan tidak akan kembali lagi. Kebutuhan mahasiswa secara umum perlu dipahami terlebih dahulu. Kebutuhan ialah segala sesuatu yang diperlukan oleh manusia untuk kehidupannya. Apabila dipandang dari sudut pendidikan, kebutuhan mahasiswa adalah terkait dengan kebutuhan aktualisasi diri. (Tampubolon, 2001: 88).

Berdasarkan uraian tersebut di atas, yang dimaksud dengan kualitas pelayanan adalah pelayanan yang memenuhi syarat, agar pelayanan memungkinkan untuk menimbulkan kepuasan pelanggan. Adapun indikator dalam penelitian adalah bukti langsung, kehandalan, daya tanggap, jaminan, dan empati.

Perguruan tinggi merupakan industri yang berinteraksi langsung antara penyedia jasa dengan pemakai jasa. Terdapat lima derajat yang menentukan kualitas perguruan tinggi berdasarkan derajat kepentingan relatifnya di mata pelanggan, di antaranya keandalan, daya tanggap, jaminan, empati, dan bukti fisik.

Pelayanan akademik merupakan pelayanan kependidikan yang berkaitan 
langsung kepada pelanggan primer yakni mahasiswa dari perguruan tinggi yang meliputi kurikulum, silabus, rancangan mutu perkuliahan, satuan materi sajian, penyajian materi, evaluasi, praktikum, dan pembimbingan. Dikatakan demikian, karena perguruan tinggi diibaratkan sebagai industri yang jasanya mempunyai produk pendidikan yang terdiri dari jasa akademik, jasa penelitian, jasa pengabdian pada masyarakat, jasa administrasi, dan jasa ekstrakurikuler.

Kualitas pelayanan akademik adalah hal yang sangat penting dalam lembaga pendidikan. Pelayanan akademik dikatakan berkualitas apabila sesuai dengan kebutuhan pelanggannya. Kualitas pelayanan akademik adalah nilai yang diberikan oleh pelanggan mengenai sejauh mana layanan akademik yang diberikannya. Pelanggan, dalam hal ini mahasiswa, akan mengatakan bahwa pelayanan akademik berkualitas apabila sesuai dengan spesifikasi mereka. (Rambat, 2006: 163).

Pelayanan akademik merupakan salah satu komponen yang harus terpenuhi dalam pendidikan. Pelayanan memiliki lima indikator yang harus terpenuhi, di antaranya:

1. Bukti langsung, meliputi fasilitas fisik, perlengkapan, pegawai dosen atau karyawan, dan sarana komunikasi.

2. Kehandalan, yakni kemampuan memberikan pelayanan yang dijanjikan dengan segera dan memuaskan.

3. Daya tanggap, yaitu keinginan para staf untuk membantu para pelanggan dan memberikan pelayanan dengan tanggap.

4. Jaminan, mencakup kemampuan, kesopanan, dan sifat dapat dipercaya yang dimiliki oleh para staf, bebas dari bahaya, risiko atau keraguan.

5. Empati, meliputi kemudahan dalam melakukan hubungan, komunikasi yang baik, dan memahami kebutuhan para pelanggan.

Berdasarkan beberapa indikator tersebut di atas, akan memberikan kepuasan kepada mahasiswa apabila telah tercapai seluruhnya dengan diberikan pelayanan yang berkualitas yang ditandai dengan adanya kenyamanan mahasiswa dalam menerima pelayanan akademik yang diberikan oleh perguruan tinggi dan biaya perkuliahan yang diimplementasikan ke dalam nilai yang sesuai dengan harapan mahasiswa.

Berdasarkan uraian tersebut di atas, maka dapat diambil kesimpulan, bahwa strategi yang dapat dilakukan untuk meningkatkan kualitas pelayanan akademik pada perguruan tinggi adalah ketersesuaian antara variabel kualitas pelayanan dengan variabel kepuasan akademik mahasiswa.

\section{KESIMPULAN}

Berdasarkan hasil dan pembahasan tersebut di atas, maka dapat disimpulkan, bahwa strategi yang paling tepat dalam meningkatkan kualitas pelayanan akademik pada perguruan tinggi adalah dengan meningkatkan variabel yang ada pada kualitas pelayanan secara nyata, keandalan, responsivitas, jaminan, dan empati, dengan dibuktikan dengan ketersesuaian yang ada di lapangan, di antaranya kesesuaian kurikulum antara harapan dan kenyataan, kesesuaian sarana dan prasarana perkuliahan antara harapan dan kenyatan, kesesuaian pelaksanaan perkuliahan antara harapan dan Copyright (C) 2020, Universitas Muhammadiyah Metro|48 
kenyataan, dan kesesuaian pembimbing akademik antara harapan dan kesesuaian.

\section{E. DAFTAR PUSTAKA}

Arikunto, Suharsimi. Prosedur Penelitian

Suatu Pendekatan Praktik. Jakarta:

PT. Rineka Cipta, 2006.

Annur, S., \& Suhono, S. (2019). Implementasi manajemen pergruruan tinggi (studi kasus pada ptkis kopertais wilayah vii sumatera selatan). JMKSP (Jurnal Manajemen, Kepemimpinan, dan Supervisi Pendidikan), 4(1), 67-75

Asnawan, A. (2021). Enhancement Integrated Quality Management in Islamic Education Institutions. Bulletin of Science Education, 1(1), 42-49.

Gasperz, Vincent. Manajemen Kualitas: Penerapan Konsep-Konsep Kualitas dalam Manajemen Bisnis Total. Jakarta: Gramedia. 2002.

Hasibuan, Melayu S. Manajemen Sumber Daya Manusia. Jakarta: Bumi Aksara, 2001

Herawati, S., Arafat, Y., \& Puspita, Y. (2020). Manajemen Pemanfaatan Sarana Dan Prasarana Pembelajaran. Attractive: Innovative Education Journal, 2(3), 21-28.

Moleong, Lexy J. Metodologi Penelitian Kualitatif. Bandung: PT. Remaja Rosdakarya, 2005.

Notoatmodjo, Soekidjo. Pengembangan Sumber Daya Manusia. Jakarta: Rineka Cipta, 2009.

Rachmawati, Ike Kusdiyah. Manajemen Sumber Daya Manusia. Yogyakarta: Penerbit Andi, 2008.
Rusmini. "Peningkatan Mutu Lembaga Pendidikan Tinggi melalui Pengembangan Sumber Daya Manusia.” Jurnal Peningkatan.

Sularso. Pembelajaran Memasuki Era Kesenjangan. Jakarta: PT. Sinar Agape Press. 1997.

Tahir, Wahid. "Pengembangan Manajemen Sumber Daya Manusia terhadap Peningkatan Mutu Pendidikan.” Jurnal Pengembangan Manajemen Sumber Daya Manusia. Vol. VI. Nomor 1. (Januari-Juni 2017).

Tampubolon. Perguruan Tinggi Bermutu Paradigma Baru dan Manajemen Pendidikan Tinggi Menghadapi Tantangan Abad ke-21. Jakarta: PT. Gramedia Pustaka Utama. 2001.

Tilaar, H. A. R. Manajemen Pendidikan Nasional. Bandung: PT. Remaja Rosdakarya. 1994.

Lupiyoadi, Rambat.Manajemen Pemasaran. Jakarta: Salemba Empat. 2006. 